\title{
The Politics of US Feminist Internationalism and Cuba: Solidarities and Fractures on the Venceremos Brigades, 1969-89
}

\author{
Karen W. Tice ${ }^{1 *}$
}

Published: March 19, 2018

\begin{abstract}
Despite US travel bans to Cuba, a wide spectrum of US feminist and radical activists defied and crossed geo-political borders to participate in unique modes of solidarity activism and alliances with Cuba revolutionaries. Based on the narratives of US feminist political travellers who joined the Venceremos Brigades, an anti-imperialist radical education project, this article analyses the difficult conversations about feminism, gender politics, homophobia, racism, cultural imperialism, revolutionary priorities, social change strategies, and intersectionality as well as the productive organisational linkages that were generated by this political travel. This article highlights how political differences were both managed and/or silenced within transnational activist encounters, and concludes by suggesting the import of these debates for building and sustaining multi-issue and coalitional affinities within contemporary transnational feminist organising and solidarity delegations.
\end{abstract}

Keywords: Venceremos Brigades, transnational feminism, solidarity delegations, cultural imperialism, geopolitical border crossings

\section{INTRODUCTION}

Beginning in the 1960s, and partly as a response to the liberation struggles occurring across the globe, many US activists claimed political kinship and linkages between US racial and class struggles and those occurring in Vietnam, Angola, China, Nicaragua, Chile, and Cuba. Embracing anti-imperialist and international solidarity discourses, many US radical left activists extended their analyses of injustice to include critiques of imperialism, colonialism, war, militarisation, and capitalism. By identifying themselves as part of an imagined international coalitional community of third world liberation struggles and solidarities, US radical activists increasingly participated in transnational circuits of travel as revolutionary travellers, solidarity workers, and witnesses traversing geo-political borders as members of brigades, study groups, and delegations to Vietnam, China, and Cuba.

A wide spectrum of New Left, Civil Rights, and feminist activists, with both shared and disparate political analyses, challenged the US imposed travel bans to Cuba. ${ }^{1}$ This was the case despite the politically-conservative and imperialistic US political landscape and its securitarian policies of militarism, law and order, state and FBI surveillance of activist groups, and police repression during the era of Nixon, Reagan, and the religious right in the 1970s and 1980s. In this article, I focus on the Venceremos Brigades (VB), an anti-imperialist radical education and Cuban solidarity project, established by members of the Students for Democratic Society in 1969. The VB, a multi-ethnic and mixed-gender organisation, is the longest lasting political organisation dedicated to Cuban solidarity work having sent more than 8,000 US activists to Cuba over the past few decades. Despite a long history of ideological strife about race, gender, class, sexuality, cultural imperialism, and coalition politics, the VB is in its $48^{\text {th }}$ year of operation. The VB remains committed to creating strategic unities among US radical activists and Cuban revolutionaries. Its goal is to foster anti-imperialist consciousness, internationalist solidarities and linkages through political education, and collective work, both with Cuba and within the US radical left.

\footnotetext{
${ }^{1}$ For excellent studies of the overlaps and differences in political priorities and organising strategies within and between the New Left, Civil Rights, and feminist organisations see Evans (1980); Van Gosse (2005); Spencer (2008).
} 
Travel to socialist Cuba as members of the VB generated a spectrum of emotions and reactions including praise, critique, and dislocation among US radical feminist activists. Not only were the Venceremos Brigades internally beset by tensions produced by US racism, sexism, classism, and homophobia but, for some of these feminist travellers, positioning themselves in solidarity with Cuban socialism was challenged by the vestiges of racism, sexism, and homophobia that they witnessed in Cuban social life and revolutionary priorities. Additionally, since the VB brigadistas lived and worked together in Cuba in very intimate conditions, they had not only to navigate the unfamiliar political and cultural ethos of revolutionary Cuba and language differences but they also had to traverse relational borders and the very contentious politics of power and privilege within the brigades. Additionally, some of the brigadistas struggled to bridge VB strict mandates governing cultural imperialism and how to reconcile their misgivings about Cuban gender, race, and sexuality politics without imposing US-centric notions of women's liberation.

This article is based on published oral histories of members of the VB, published and unpublished travel journals, radical left, gay, and feminist newspapers (Triple Jeopardy, Off Our Backs, Gay Flame, Gay Community News, Ramparts, Great Speckled Bird, Liberation News Service, Black Scholars), and organisational and personal archives. I analyse how solidarity travel encounters generated political divisions and factions but also, in some cases, productive debates, friendships, and rhizomatic networks that supported domestic US coalitional building among US activists across ethnic, gendered, political, and class borders. Although a few feminist scholars have analysed the politics of US solidarity delegations to Vietnam, China, El Salvador, Nicaragua, and Chiapas, Mexico, such solidarity activism, especially that of the Cuban VB, has remained relatively understudied in feminist scholarship. ${ }^{2}$ Many feminist scholars have argued that cross-border alliances and solidarity activism are essential forms of transnational praxis. They require ongoing political reflexivity, dialogues, accountability, and responsibility about domination, location, translation and representation, socio-political identifications, asymmetrical risks and resources, a priori simplifications of geographies, histories, and resistance, and unravelling the colonialist impulses of superiority, saving and rescue. ${ }^{3}$ This article analyses how such exigencies were enabled and/or disabled on the VB.

The VB generated extensive debates about autonomous women's organisations, relationships to the state, beauty and body politics, and the relative importance of imperialism, classism, racism, sexism, and homophobia to radical solidarities. By exploring the affects and after effects of this personalised and embodied form of transnational travel and solidarity in Cuba throughout the 1970s and 1980s, I highlight the fault lines, silences, and tensions that occurred within the VB. I explore how intersectional relations of power including imperialism, sexism, homophobia, racism, and cultural imperialism were framed, prioritised, or dismissed within the VB and how such relations shaped the stories told by US feminist brigadistas about their engagements with Cuban gender politics and revolutionary processes. I discuss the impact of these tensions on subsequent personal and organisational linkages and schisms among US solidarity activists and their effects on their post-Cuba activism. In doing so, I hope to supplement the rich scholarship of radical left internationalism and anti-imperialist struggles as well as the work of scholars who have analysed the ways US activists, in general, responded to homophobia and racism in Cuba, by highlighting the understudied accounts of radical left women that explicitly claimed an identification with various US women's liberation groups. ${ }^{4}$ The problematics and possibilities of cross-border delegations such as the VB and the forging of feminist anti-imperialist internationalism and solidarities to challenge conservative, neo-liberal, militaristic, and imperialistic politics are as urgent and relevant now as they were during the beginning of the VB. This is especially so in light of the continuing popularity of solidarity delegations as a contemporary mode of transnational feminist practice such as the recent 2011 delegation of Indigenous and Women of Color Feminists to Palestine. By analysing the accounts of radical US left feminists in Cuba, this article provides a critical lens for assessing feminist claims of transnational solidarities and border collaborations as well as affirms the ongoing importance of interrogating how one's national, cultural, political, and historical specificities can prefigure and limit transnational feminist solidarities.

\section{POLICIES, POLICING, AND PERILS ON THE VB}

The Cuban revolution and its defiance of US power unleashed a complex emotional landscape of desire, yearning, romanticism, dread, repression, and critique across the US political spectrum. This highly charged affective political climate intensified the many schisms about armed violence, pacifism, and the primacy of

\footnotetext{
${ }^{2}$ Insightful studies of international solidarity delegations include Wu, 2013; Khasnabish, 2008; Hobson, 2016; Weber, 2006; Blackwell, 2014; 2011.

${ }^{3}$ For insightful studies of the tensions between women from the North and Global South see Johnson-Odim, 1991; Desai, 2015; Ghodsee, 2010; Falcon, 2012; and Mohanty, 2003.

4 See Gronbeck-Tedesco, 2015; Latner, 2013; Young, 2006; Pulido, 2006; Gitlin, 1987.
} 
oppressions among the disparate Cuban revolutionary travellers. At the same time, the attacks by the right-wing politicians on the $\mathrm{VB}$, also produced organisational imperatives for unity based on rigid standards for behaviour while in Cuba, and the stifling of misgivings about the Cuban revolution.

Rebel Cuba was and is demonised by many in the US as a communist abomination that threaten-ed/s the security of the US. As a result, the VB, as a Cuban solidarity organisation, was subject to US governmental harassment. In 1970, for example, Mississippi Senator James Eastland, chair of the US Senate Committee on Internal Security, fearing the importation of Cuban socialism to the US, promised that the Senate Internal Security committee would prevent US political pilgrimages and solidarity brigades to Cuba to support the sugar and fruit harvests. Eastland asserted:

We intend to light the shadows of this vicious operation [VB]; to drive from these shadows these missiles in human form--which have been fashioned on this communist island and fired at America. We want our people to be aware of the direct chain from Cuba which reaches into our cities, our campuses, our conventions, our lives which threatens the life of this Republic (US Congressional Record, 1970: 7465).5

Such rabid opposition to Cuba and the brigades played an important role in the VB's subsequent policing of Cuban critique and political dissent on the brigades, resulting in heavy-handed notions of what constitutes cultural imperialism, revolutionary priorities, and proprieties for the brigadistas in order to avoid co-optation by right-wing anti-Castro forces. By evoking the perils of cultural imposition to stifle internal critique, the National Committee of the VB used the politics of cultural imperialism to manufacture consent for its organisational agendas and priorities.

Despite this volatile climate of US hostilities towards Cuba and the surveillance of US Cuban solidarity activists, numerous mixed gender, multi-ethnic work and study exchanges crossed enemy lines to go to Cuba. In addition to the VB, exchanges were also organised by various US progressive and radical left groups including the Student Nonviolent Coordinating Committee, Student Committee for Travel to Cuba, Fair Play for Cuba, Black Scholars, Antonio Maceo Brigades for Cuban Americans, Committee of Returned Volunteers, National Lawyers Guild, Vietnam Vets Against the War, Pastors for Peace, and the Center for Cuban Studies among others. Travelers to Cuba included members of the SNCC, Black Panthers, La Raza, Young Lords, Asian American Political Alliance, Atlanta Lesbian Feminist Alliance, Third World Women's Alliance, Quakers, and socialist/progressive university faculty/student groups. ${ }^{6}$ Additionally, the Cuban government itself invited and organised exchanges with US radical educators and Black activists. These groups were by no means united by political ideologies, especially about revolutionary priorities and strategies regarding violence, machismo and sexism, racism, internationalism, and homophobia in Cuba and the US. They had many different motives and hopes for going to Cuba including seeking revolutionary inspiration for struggles back home, making concrete contributions to a socialist revolution, and becoming outlaws to US bans to challenge imperialism.

The first Venceremos Brigade in 1969 consisted of two hundred activists that encompassed a wide spectrum of movement organisations including the Black Panthers, La Raza, SDS, New University Conference, High School Student Union, Bread and Roses, Weathermen, and the Committee of Returned Volunteers among others. ${ }^{7}$ This first VB brigade was designed specifically to politically, physically, and materially support the 1970 Cuban sugar harvest, and help undermine US imperialism by helping to stabilise the Cuban economy. Bernadine Dohrn, Karen Ashley, Diane Oughton, and Julie Nichamin, who were at the centre of the ideological splits within the Students for a Democratic Society and identified with the bellicose politics of armed struggle as espoused by the Weather Underground, were key players in organising the VB. ${ }^{8}$ Some served on the National Committee of the VB in its early stages as well (Sales, 1973). Numerous skirmishes occurred between those VB members affiliated with the Weathermen and those who were not. Those affiliated with the Weathermen faction asserted that the accomplishments of the Cuban revolution since it violent overthrow of Batista in 1959 should galvanise US radicals to consider armed struggle to 'bring the war home'. Some years afterwards, Margot Adler vividly described the intensity of political exchanges between the highly macho members of the Weathermen and other brigade members over political actions:

\footnotetext{
${ }^{5}$ The VB was again the subject of Senate Hearings in 1972, which included testimony by FBI informants, to explore the question of whether or not the brigades constituted a threat to US internal security.

${ }_{6}^{6}$ On Fair Play for Cuba Gosse, 1993.

${ }^{7}$ The Committee of Returned Volunteers consisted of ex-Peace Corps activists who advocated that the Peace Corps should be abolished since its conservative practices supported corporate and imperialist interests.

${ }^{8}$ The Weatherman advocated militant armed struggle as the means for toppling white supremacy, imperialism, and capitalism. Women in the Weathermen organisation believed themselves to be members of a women's fighting army. They criticised feminism for its relative neglect of war, race, and class and advocated the position that 'political power grows out of the barrel of a gun and the struggle to use political power against the state is the struggle for our liberation' (Jacobs, 1970: 190). For more on the Weathermen, see Churchill, 2007; Boudin and Robbins, 1969; Jacobs, 1970.
} 
We spent ten days fighting over how to write a letter of support to the Black Panthers after one of their leaders was murdered in cold blood. The Weathermen held several meetings with us to explain their ideas to the rest of us (Adler, 1998: 247).

Conflicts between Weatherwomen and the brigadistas of the Boston-based Bread and Roses Collective anticipated the political minefields and ideological schisms that would repeatedly erupt within the VB throughout the 1970s and 1980s in regard to women's liberation. Members of the Weatherwomen as well as some other members of the VB National Committee were highly critical of the 'separatist' US white women's movements their 'sad eyed sisters' who did not clearly define the enemy as US imperialism, capitalism, and racism. Instead, they focused on 'empty transitional demands' (Jacobs, 1970: 184-191). Further, the Weatherwomen argued that white women's focus on equal rights was racist since it did not promote an 'international insurrection against imperialism' (Honky Tonk Women in Jacobs, 1970: 185). More radically, they argued:

We demand not Bread and Roses to make our lives a little bit better and shield us from struggle a little more but bombs and rifles to join the war being fought all over the globe to destroy the motherfuckers responsible for this pig world (Honky Tonk Women in Jacobs, 1970: 190).

Some members of the Boston-based Bread and Roses collective opposed domestic terrorism as a strategy. Nonetheless, they acknowledged that some criticisms of US feminism were well founded, especially after visits to Cuba and Vietnam helped to foster their understandings and commitments to internationalism. They confessed that their 'internationalism had been sporadic and apologetic' and that they had:

ignored that imperialism is part and parcel of the very capitalism as it exists in the U.S. (...) The Weathermen pushed us to realise we must have a more complete class strategy for fighting and winning in this country (Bread and Roses Collective, 1970: 192-97).

The primacy of an anti-imperialist commitment shaped the overall policies of the VB. This included what I term their 'radical left cultural etiquette,' i.e., the norms that delineated the ideological commitments, behavioural, and work conventions for members of the VB. The National Committee of the VB asserted for instance: "This trip to Cuba will not be like the usual trips dedicated to radical tourism. People will be going to work--hard work" (Movement, July 1969:10). Julie Nichamin, a member of Weatherman, stated that the selection of potential brigadistas were made on the basis of how they felt about 'the revolutionary movement, about the kind of society we need in the US and in Cuba'. She reported: "We asked about the attitude towards the black subversive movement, attitudes towards the struggle of the Vietnamese people" (Bethel, 1970: 13). Recruitment processes were also designed to ensure equal numbers of white, black, and brown people. The latter two groups were designated as "Third World peoples' by the National VB committee and given leadership roles on the brigades. Bernard Hughes, a member of the second VB brigade, critiqued this monolithic characterisation of the solidarities of Third World peoples, however, arguing that it was problematic to assume uncomplicated unities among Third World brigadistas since 'none of us had actually functioned as Third World people among other Third World people (...) There was lots of things we did not know about each other and there were many antagonisms' (Levinson and Brightman, 1971: 20) (sic). As a result, a Third World caucus was formed on each brigade and in this context, Puerto Rican, Asian, Native American, Chicano, and Latin American women of colour offered 'Third World' seminars for each other, the Cubans, and white US brigade members. A member of the Asian caucus noted the separation between people of colour: "Asian communities have been isolated from the other Third World communities and for the most part people of the brigade don't know our struggles" (Louie, 2008). These seminars pointed both to the commonalities as well as the historical and cultural differences among Third World women.

The composition of the National Committee changed after the first year and included three women, five men, five people of colour, and three whites. This committee, like many subsequent VB committees, elaborated the goals of the VB to emphasise the importance of strategic unity among US radical activists groups. In 1971, the VB declared the following goals:

To develop solidarity with the Cuban revolution and peoples of the Third World; To promote the political formation of the progressive forces in the US through the brigade process in Cuba and in the US; To educate the US movement to an anti-imperialist consciousness and to the necessity for and possibility of unity in strategic terms; To facilitate dialogue among different US movement groups as they work in the context of a common and constructive task (Venceremos Brigade, 1971: 4).

Would-be recruits were warned 'that the VB is not a left wing travel agency. Participation in Cuba is only one phase of the project. Just as important are the Brigade activities carried out in the US' (Venceremos Brigade, 1971: 4). Before leaving the US, new members of the brigades were required to participate in an orientation process that 
was designed to foster 'strategic unities', 'anti- imperialist consciousness', 'an internationalist perspective', and 'collective work attitudes' (Venceremos Brigade, 1971: 11). The brigades were organised into regions and zones to facilitate post-Cuba, regionally based organising back in the states. In order to develop group cohesion and collectivity, regional brigades engaged in a variety of pre-departure group activities. Some groups studied Spanish together, some went on group camping trips, some organised fundraising activities, and others engaged in political activist projects such as building housing for US farmworkers. All VB travellers were required to attend predeparture political education meetings that included films, readings on socialism and Cuba, and rap sessions to discuss their motivations for going to Cuba and their prior political experiences.

In 1971, the VB National Committee revised its guidelines to underscore the importance of subduing critique and dissent and strengthening unity. These new guidelines stated:

The VB will not comment on, analyze, or attack movements within the US. Our propaganda will not be sectarian or derogatory. While understanding emotions play a role in propaganda, we must keep in mind the consequences of all of our statements. That is, we must struggle against romanticizing Cuba or seeming uncritical, or supercritical. VB propaganda should emphasize the growing unity of antiimperialist movements (Venceremos Brigade, 1971: 4).

Despite these aspirations for strengthening anti-imperialist coalitions between US brigadistas while in Cuba and back in the US, implementing and sustaining these commitments to collaboration in practice would prove to be challenging. As we shall see, this vision for group solidarities and strategic unities was often stymied by sectarianism and compulsory politics.

Traveling as members of the solidarity brigades to revolutionary Cuba was far removed from the prerevolutionary tourism that had included visits to casinos, nightclubs, beaches, and resorts. Breaching international border-crossing bans to work as cane cutters and fruit pickers for more than two months in Cuba was arduous. Even though the brigadistas of the VB were told that cutting ten feet high stalks of sugar cane in the heat would be gruelling, thousands embarked on trips to Cuba to do just that. For many brigadistas however, political and personal polarisations, combined with the intimacy of traveling and living in mixed-gender and interracial groups along with the daily political education activities, would, at times, prove to be as demanding as facing the sugar cane and the heat of Cuba.

\section{ON THE BRIGADES: REVOLUTIONARY HOPES AND INSPIRATION}

Many US brigadistas have spoken of the deep emotional impact and political inspiration that their Cuban solidarity work produced especially for their personal and political growth. Many brigadistas noted that their experiences in the VB fostered an acute awareness of the international consequences of US capitalism, opportunities to widen their activist networks, build friendships, participate in study groups, and strengthen their affective connection to broadly construed, non-specific, notions of Third World struggles. At the same time, some brigadistas were more ambivalent about revolutionary change in Cuba and some were less optimistic about possibilities for strategic unities among US activists.

Numerous women of colour defined their Cuban experiences as pivotal for their political development. Members of the Third World Women's Alliance noted that their 1972 trip to Cuba:

Helped us understand more precisely the relationship between those [Cuban] struggles and the struggles of Indo-Chinese people as well as liberation struggles within the US. It has helped us understand better just what imperialism means in the daily lives of the Cuban people and of people around the world. Above all, it has made it clearer what we must do in our day-to-day work (Triple Jeopardy, 1,4, 1972: 14).

Miriam Ching Yoon Louie, a member of the Asian American Political Alliance, noted:

We cut Cuban sugar cane to break the US government blockade and show our solidarity with those cheeky brown folks who had the nerve to make a revolution right under Uncle Sam's nose. In the wake of Martin Luther King's assassination, Watts, rebellions burning across the face of Urban America and Indian country and full-scale US intervention in Southeast Asia, the Brigade enabled us to hook up with young bloods from communities of color across the US or in the 'belly of the beast' as it used to be called back in the day (Louie, 2008: 260).

Another brigadista described the political allure of Cuba as an opportunity to learn about radical anti-colonialist and imperialist liberation struggles, observing that: 
We who participated in the civil rights movement, the battles for self-determination of Blacks, Chicano, Native American and Puerto Rican people, the student protests, the anti-war movement, the fight for women's liberation, could never be convinced that our society could be healed without deep and fundamental change. We began to look outside the borders of the United States towards those who were already building societies of justice, equality, and human dignity: we were ready to learn from their examples (Venceremos Brigades, 1974: 3).

One African American brigadista was described as lamenting the fact that she had missed much of the early 1960's civil rights organising and that she was excited about the opportunity to be a part of the brigades in order to fight US racism:

Now at last she can get to Cuba-her Selma (...) she sees a long struggle [against racism] in the offing, she wants to prepare her children for reality. The Cuba trip will help to do that (Levinson and Brightman, 1971: 49).

Espaeranza Martell, a Puerto Rican activist, explained that:

... for two and half months we worked, played, studied, and travelled around Cuba working shoulder to shoulder and learning from revolutionaries from all over the world (...) This trip to Cuba transformed and saved my life (Martell, 1998: 177).

Linda Burnham, a member of the Third World Women's Alliance, noted the significance of her Cuban travels, especially the VB's political education and collective work projects:

What was positive about the experience is that there was a deep learning experience on the front end before we ever got there [Cuba]. There was a big emphasis on political education and trying to prepare young people to understand something about colonialism, something about US relations with Cubawhat US capitalism is about and how it functions in the world, and studying about racism. Being in the VB was the first time I had an opportunity to do fairly systemic political study. I think it really molded me as a political activist and also as someone who I think from that time forward sustained an international vantage point about what was going on in the world (Burnham, 2005: 17-18).

Although the VB was credited with fostering an international political analysis, at the same time it also imparted some difficult lessons about the fraught nature of VB's coalitional politics. Burnham concluded that:

There were complicated and difficult lessons to be learned about internal political struggle, when everybody's supposed to be kind of on the same political agenda, but it does not quite work out that way (Burnham, 2005: 18).

Such cautions about the difficulties of sustaining coalitions across national borders and within the brigades were echoed by other brigadistas. Chicano activist Gino Lofredo argued that the challenges of overcoming the internalisation of capitalist sensibilities and the trouble caused by right-wing opposition to the VB made solidarities a contentious process. She noted:

We joined the brigade as members of the Third World with a revolutionary seriousness that even surprises us, and we attended the first preparatory meetings and orientation classes. Gradually doubts begin to emerge: Is this an Amerikan-style traveling circus or an act of solidarity with the people of socialist Cuba? (Levinson and Brightman, 1971: 365).

She also reported that the persecutions of the FBI caused:

... a swamp of tensions, conflicts, ancient hatreds; an abyss of incomprehension, and all the other products of the capitalist society (Levinson and Brightman, 1971: 365).

Finally, Frances Beal acknowledged the importance of Cuba for women of colour 'in terms of our kind of evolving consciousness around both race and class issues' and noted that:

... some people had some differences about the speed at which some of these old problems were being addressed in Cuba. But I think that many of us witnessed in Cuba the possibility of a society in the future that was free of racism and the possibility of a society in the future in which women played an active and equal role (Beal, 2005: 44). 
The uncertainties expressed by Beal about the pace of revolutionary change in Cuba would be echoed by many other brigadistas and, in some cases, produced deep disappointment with Cuban socialism.

\section{THE FRAUGHT POLITICS OF RACISM ON THE VB}

The Cubans will not tell us how we should make our revolution. And they expect the same from us. This is the essence of their position, one which is too often alternatively forgotten as we make heroes and scapegoats of them. If they influenced our internal politics it was because we weren't sure of ourselves, our movements, our analyses (Staffens, 1971).

Cuban racial politics produced a jumble of emotional and political insecurities for those identified with the US women's liberation movement. As the Bay State regional committee of the VB aptly noted, "problems such as racism, cultural chauvinism and sexism which exist among US people do not simply disappear because North Americans have touched socialist soil" (Latner, 2013: 59). Tensions arose between white women and people of colour on the brigades. Martha Trolin, a white brigadista, spoke of her misunderstanding with a Puerto Rican brigadista who explained that:

... her PR movement had to be unified - men and women (...) she does not understand why we fragment our movement with Women's Liberation. She does not understand the problems of an alienated middle class (just as I do not understand those of the colonised). My concepts sound bourgeois to her and hers sound narrow to me (Levinson and Brightman, 1971: 190).

Heidi Staffens, a white women member of the $4^{\text {th }}$ brigade, argued that the brigade experiences brought US racism to the surface. Staffens recounted a story in which black men came to a meeting of white and Third World women (a designation used by the VB for all women of colour). None of the women dared to ask the black men to leave and she attributed this to both the insecurity white women felt about the revolutionary validity of the women's movement as well as the rampant racism on the brigades. Staffens concluded:

We are afraid of Third World people, and are afraid of being called racists. We viewed Third World people as other than human - they were heroes, or noble savages - but they were not real people. They were not to be confronted by white people on important issues. The dynamic escalated and many whites and Third World avoided dealing with each other (Staffens, 1971).

Bernard Hughes, an African American brigadista, noted that racism was especially apparent in regards to African Americans on the brigades:

The relationship between black and white North Americans in Cuba was basically the same as in the US. Whites avoided dealing with racism... White people related more easily to the Cubans than to black Americans. They didn't have the long history of being racist towards Cubans (Levinson and Brightman, 1971: 198).

Hughes also pointed out that both at brigade meetings and in the cane fields many whites would not accept Third World Leadership and some tried to talk for black people in general. Alternatively, many white and black brigadistas believed that whites needed to confront their tendencies to become immobilised by guilt, shame, and fears of being labelled a racist. One white brigadista, writing anonymously about Third World solidarities and racism, asserted:

In Cuba many whites learned that a united front cannot be formed simply by proclamation. In order for the Third World movements to unite and then join with the white revolutionary movement, aims and goals must be well defined (Levinson and Brightman, 1971: 220-222).

Further, she urged white radicals to do their 'homework' and move beyond feelings of guilt and fear of accusations of being racists:

Our obligation as whites is to attack the racist system in every way possible and at the same time expose the roots of that system, the capitalist economy. It is essential that whites analyze their own communities and see what its revolutionary potential is (...) Until we do this, unity with Third World people cannot but be superficial and opportunistic (Levinson and Brightman, 1971: 220-222).

Although the importance of Third World leadership and solidarity were articulated as central goals of the VB, the realisation of these goals proved to be elusive as US racism permeated the relationships within the VB. By 
positioning US people of colour as part of a generic category of Third World people, many white brigadistas could celebrate abstract disembodied notions of Third World solidarity at the same time that white racism on the brigades flourished.

\section{SEXISM, RADICAL COMPORTMENT, AND TRANSCULTURAL ETIQUETTE}

Although the VB had taken a strong stance in 1971 on the importance of achieving strategic unity, maintaining non-sectarian positions, and refraining from attacks on various US liberation movements, the VB National Committee claimed the right to limit participation on the brigades not only for reasons of space and group composition but also 'comportment' (Venceremos Brigade, undated: 13). This nebulous category of 'comportment' or as I think of it, radical left transcultural etiquette, helps to reveal how notions of cultural imperialism increasingly were used to police and stifle differences of opinion about revolutionary practices, gender, race, and class priorities not only in Cuba, but also among US radical liberation movements and within the VB brigades themselves. Enforcing proper comportment allowed the National Committee to privilege certain political commitments and movements, mainly anti-imperialism, and, in doing so, to minimise gendered critiques of Cuba and the brigades themselves. The VB strongly warned that US radicals 'go to Cuba as guests, not as political tourists. We are there to express solidarity and learn about revolutionary accomplishments. This does not mean that we view Cuba as a perfect society, accepting everything the Cubans have done. The Cubans recognise that they have made errors and they are working to correct those errors. The course they have chosen may not always be what you have chosen in their place. But it is their country, their revolution' (Venceremos Brigade, undated: 13). The issue of US women's and Black liberation organising was highlighted as potentially troublesome on the brigades. The National Committee stated:

Some brigadistas who are active in national minority and women's groups, for example, expect Cuban blacks to share the attitudes of Blacks and women in the US. We should certainly take advantage of our visit to talk with Cubans about why Cuban blacks view themselves simply as Cubans or why the Cuban women's movement views itself as part of the revolution rather than independent and adversarial. You must respect cultural and historical factors and avoid cultural imperialism while in Cuba (Venceremos Brigade, undated: 14).

Despite the construction of US women's liberation as potentially vexing to the VB, many US feminists, with deep affective attachments not only to socialist revolutionary change and anti-imperialism but also to various US women's liberation movements, joined the brigades. They faced numerous challenges including navigating internal brigade politics, bridging and understanding the enigmas of Cuban gender politics, and reflecting on the flaws and strengths of US women's organising. Elizabeth Sutherland Martinez, a US Chicano activist who had travelled to Cuba with SNCC in 1967, described Cuban gender and sexual relations as a 'curious but not so surprising mix of past, present, and future, of revolution, and conservatism' (Martinez, 1969: 97-100). She concluded that the machismo of the revolutionary 'New Man' continued to overshadow Cuban women as 'organizers and producers' of revolution (Martinez, 1969: 97-100)..$^{9}$ Likewise, Gene Bishop, a brigadista in 1970, recalled:

We had come to Cuba with our heads full of the women's movement but worried about legendary Latin machismo, excited to see what it was like for women in a country in revolution. But when we tried to figure it out, it wasn't so easy...An underdeveloped country, a different cultural history, years of North Americans imposing their ideas on Cuba, and a Revolution in which some things changed so quickly that you could not pinpoint them minute to minute, all made it hard to translate the position of Cuban women into terms we could understand (Levinson and Brightman, 1971: 246)

Bishop concluded that while there was no doubt that Cuban women were more liberated than before the revolution, there were still so many examples of women in 'traditional roles existing side by side with a revolutionary contradiction' (Levinson and Brightman, 1971: 246.)

Many brigadistas did read Cuba with US eyes, using the prefigured lens of their respective US based gender priorities, ideologies, and frames. Some brigadistas were uneasy about the perceived failure to prioritise gender as a primary oppression on the island. They identified many gender troubles in Cuba, especially the lack of attention given to feminist consciousness-raising, the lack of autonomous women's organisations, gendered job segregation, and the persistence of Latin machismo. Many brigadistas also critiqued the problematic body and beauty politics they witnessed in Cuba including the performances by Cuban women entertainers in the brigade camps, the large number of beauty parlours in Cuba, and the importance of beauty and femininity to many of the Cuban women

${ }^{9}$ See Serra, 2007; Chase, 2015.

$8 / 15$

(C) 2018 by Author/s 
they encountered. Finally, many women on the VB wrestled with Cuban revolutionary patriarchies including the male-dominated power structures, and double standards, i.e., the expectation that women in Cuba should be, as Castro put it, 'doubly revolutionary' which some US activists understood to mean that although Cuban women were central to the revolution, they were not equal. ${ }^{10}$ Mary Nelson, for example, concluded that Cuban women were valuable only because Cuba needed their labour to develop the revolution, not because the Cuban state was committed to gender equality (Nelson, 1968). Such revolutionary incongruities in regard to gender politics challenged some US feminist-identified brigadistas to rethink their fears of cultural imposition and their own deeply entrenched culturally-specific feminist priorities. One brigadista aptly noted that "Good, bad, liberated, nonliberated - our categories didn't work" (Levinson and Brightman, 1971: 249).

Many US feminists critiqued hegemonic gendered and racialised beauty standards that became an important basis for their assessment of the Cuban revolution. Many feminist-identified brigadistas such as Mary Nelson critiqued Cuban fashion as an significant shortcoming of the Cuban revolution observing that there was "no shortage of women in heels, tight skirts, standard Latin sexy style" in Havana since Cuban women "[had] not discovered that they are already valuable" and that there should be less importance placed on pleasing men (Nelson, 1968). Brigadista Joan Berman also critiqued Cuban beauty practices from the standpoint of US women's liberation:

In many ways Cuban women still live out their lives attempting to fulfill feminine standards. They have definite ideas about what is feminine. They spend a considerable amount of time making themselves beautiful, even in the rugged life of an agricultural worker (Berman, 1970: 12).

She critiqued the official state women's organisation, The Federation of Cuban Women's magazine, Mujeres, for including extensive fashion tips alongside its political education and for its proclamation that it was a 'feminine', not a 'feminist' organisation. She lamented that Cuban women did not see the relevance of US style women's liberation "though some understood it well enough but felt that in this moment it was more important to devote energy to tasks related to underdevelopment" (Berman, 1970: 12).

Barbara Rothkrug and Shari Whitehead were also troubled by the politics of beauty in Cuba, the sexual double standard, the continuing objectification of women, and a division of labour based on perceived gendered strength. However, they countered such perceived gender flaws by noting: "Few American women have such confidence in a future of meaningful work and security." They pointed out that in defence of beautification rituals, some Cuban women had told them that before the revolution only rich women could make themselves beautiful (Rothkrug and Whitehead, undated). Chris Camarano likewise noted the contradictions between revolutionary Cuba and the vestiges of pre-revolutionary days by observing that an article about a women's tractor brigade could be found side by side with a bikini-clad femme fatale in Cuban women's magazines. She argued, however, that 'it was hard to see fashion as a serious detrimental force' since fashion in Cuba did not serve a capitalistic consumer-commodity chain. She added:

Cuban women do not come close to American woman's oppressive mania regarding her looks, her youth, her constant self-scrutiny, her agonising self-consciousness. There is simply more engaging things around, more important things for them to be about. The revolution has a way of making Revlon et al. irrelevant (Camarano, 1971: 55).

Later on in 1978, Alice Hageman and Carollee Bengelsdorf argued that dismantling capitalism would not be enough to topple gendered hierarchies. They argued that:

...the systemic destruction of the bases of capitalism does not in and of itself spell the end of the patriarchal nexus. Revolutionary struggles must include the ideological realm and consciousness raising (Bengelsdorf and Hageman, 1978).

They concluded:

Oppression still exists. It is obvious in almost every aspect. The same woman who drives a tractor or studies at a sugar engineering school must confront ogling men on the street (Bengelsdorf and Hageman, 1978).

They complained that revolutionary Cuba still had its beauty contests such as the National Heroine of Labor and the Star of the Harvest and they further pointed out that no Cuban women had taken their husbands to court for not complying with the Family Code for shared housework as was legally possible under the code (Bengelsdorf and Hageman, 1978).

${ }^{10}$ See Guerra, 2010.

(C) 2018 by Author/s 
Many Cuban women challenged US feminist critiques of their gendered positioning within the revolution. Disagreements with Cuban women about revolution and women's liberation were not uncommon. For example, one Cuban woman working on the brigades stated:

I read all your Women's liberation pamphlets, but I do not really understand. Here we are already liberated--we do all kinds of work, we do what we want. Compare the situation now to before the revolution. (Levinson and Brightman, 1971: 246).

Chris Camarano also noted that gender was not the primary political identification for many Cuban women unlike many in the US women's movement:

For a Cuban woman to see herself as a Cuban is not for her to deny she is a women. She is saying that her being a Cuban women and a revolutionary frees her to be other things as well; frees her from what Simone de Beauvior calls her mere 'otherness in regard to the individual male or male dominated society (Camarano, 1971: 57).

Despite these critiques, some US women brigadistas expressed admiration for the many achievements of the Cuban revolution for women. They celebrated the increased mobility and independence of Cuban women as well as their enviable material security. Despite Bengelsdorf and Hageman's comment above, they heralded the passage of the 1975 Cuban Family Code which mandated that men must share child rearing and domestic responsibilities, the availability of day care six days a week and twelve-week maternity leave, the major advances that had been made in educational and workplace equality, the provision of free birth control, abortion, education, health care, and support services for women workers including workplace laundries and preferences in grocery store lines. Moreover, many brigadistas were impressed by Cuban's women's deeply emotional, optimistic, and active engagement in the revolutionary process.

Some brigadistas felt that it was more important to address US gender troubles and organisational shortcomings including racism, separateness, and classism rather than focusing on Cuban flaws. Sue Baker, a brigadista returning from Cuba in 1970, noted that Cuba had made her 'rethink the idea of a separate women's movement since women and men need to work together for radical change (Baker and Salzman-Webb, 1970: 6). Others glossed over the perceived gendered blemishes in Cuba under the banner of refraining from cultural imposition and selfdetermination. One VB brigadista asserted: "I was struck by the incomplete nature of women's liberation and Cuban hostility to homosexuality (...) but it was not our job to tell Cuba what to do but to clarify our own revolutionary possibilities". Despite her allegiance to self-determination, she concluded that US women's liberation's 'challenge to conventional sex roles might be our unique contribution to international revolutions' (Whitman, 1972: 69). Others thought that time would allow for further revolutionary changes to the gender status quo. Chris Camarano noted that Cuba had destroyed an exploitative political system and had created a material base that deinstitutionalised male chauvinism, yet these changes 'did not immediately decolonize attitudes' and thus consciousness-raising struggles must be continued (Camarano, 1971: 58). Linda Gordon also argued that assumptions about the 'status of women' in Cuba were deeply problematic since 'status was a static word' and Cuba is 'not a country. It is a movement' (Linda Gordon, 1970: 14). The revolutionary inspiration that many feminists sought in Cuba was often tarnished by what they witnessed in Cuba. However, feminists on the brigades were never monolithic in their views of Cuba. While some were disappointed by the lack of complementarity of gender priorities between the US and Cuba, others brigadistas remained hopeful that change was on its way. However, as we shall see, the issue of homophobia would provide the most potent obstacle to strategic unities.

\section{THE EXPLOSIVE POLITICS OF SEXUALITIES}

Imagine a country where women's reproductive rights are guaranteed; free abortions, birth control and sterilization on demand, paid maternity leave and free pregnancy, birth, and post-natal health care. Add the idea that the country has a Legal Family Code that by law makes husbands responsible for $50 \%$ of the housework and childcare. Throw in that the government has dedicated itself to an ambitious expansion of public low cost day care centers and is working to eliminate violence against women. Now imagine that this country is also extremely homophobic; that gays are hassled by the police, it is illegal to demonstrate "erotic" behavior to members of the same sex, and most people think gays are mentally ill. Sounds like an impossible combination? Well that country in fact exists just 90 miles south of Florida, Cuba (Ferguson, 1980: 5).

As heated as were the issues raised by women's liberation and racism, homophobia and gay liberation proved to be even more intractable, generating explosive divisions within the VB National Committee, among the VB 
brigadistas themselves, and within US radical liberation movements. While such tensions were directed towards Cuban sexual politics and homophobia, they reveal a great deal about intersectional politics, priorities, and dismissals that occurred within the radical US left, and gay and women's liberation groups. The politics of sexuality and homophobia produced some of the most virulent political critiques of the VB and Cuban policies. For many, this was a breaking point that could not be glossed over.

Cuba had a dark and haunted history in regards to homosexuality that included reprogramming camps for homosexual men in the 1960s, a gulag for removing gay Cubans perceived to be weak, counter-revolutionary subjects. ${ }^{11} \mathrm{~A}$ member of the Atlanta VB observed simply: "Cuba has an insatiable appetite for everything but homosexuality in which they are as uptight as the US" (Goodman, 1970: 8). Although the reprogramming camps were eventually abolished, homophobia persisted. The issue of homophobia exploded in the early 1970's, sparked in part by a 1970 letter from a group of Cuban gays that was sent to US radical news services describing the repression, aggression, and social isolation they experienced in Cuba. Their letter was followed by an explosive resolution passed in 1971 by the Cuban National Congress on Education and Culture that condemned the 'social pathological nature of homosexuality'. It asserted that homosexuality should be contained by banning homosexuals from working with Cuban youth, and representing Cuba abroad (Blasius and Phelan, 1997: 408-409).

This resolution received extensive coverage in the US radical press that unleashed conflicting reactions among US movement groups. ${ }^{12}$ Many were outraged while others struggled to straddle fears of cultural imperialism and their disappointments about the resolution. Gay activists continued to join the brigades but the issue of homophobia led to major rifts and changes in policy. In 1972, the National Committee of the VB revised its selection processes for the $5^{\text {th }}$ brigade by allowing only those gay activists who demonstrated that they identified primarily with anti-imperialism and not just gay liberation. This decision was justified by affirming the importance of Cuban self-determination and the need to avoid US cultural imperialism. The National Committee stated: "Our policy is based on practical considerations of the VB position in Cuba, Cuba's position towards homosexuality, the political objectives of the VB, our purpose in Cuba, our position towards Cuban policies, and the past practices of gay brigadiers" (Venceremos Brigade, 1981: 98-100). The Committee also asserted that:

The Cuban people as a whole do not accept homosexuality. There is no material base for the oppression of homosexuals in Cuba. They are not repressed in work camps or anything of that sort. But it should be clear that Cuba does not encourage homosexuality (Venceremos Brigade, 1981: 98-100).

Finally, it reminded its critics that the Congress report had involved the input of thousands of Cuban citizens who took the position that homosexuality is a 'social pathology left over from bourgeois decadence'. The Committee noted that this Cuban policy was formulated 'by the Cuban people for the Cuban people. It is not formulated for the US' (Venceremos Brigade, 1981: 98-100).

The National Committee alleged that some gay brigadistas had engaged in problematic breaches of politicalcultural brigade etiquette that included 're-educating Cubans, outright attacks on the revolution, assuming the situation in Cuba must be the same as the US, and imposing US gay culture on Cuba' (as for example, by parading in drag in a Cuban town). It concluded that such behaviors revealed a 'lack of understanding of the position of Brigadistas in Cuba as guests of the Cuban revolution and lack of affirmation of the Cuban peoples' right to selfdetermination':

While this does not mean we deny the importance of dialogue, we are not in Cuba to carry out confrontations over disagreements. As guests we must realize that internal questions can only be answered by Cubans, answers cannot be imposed by the outside.

The National Committee, however, did not impose a total ban on gay activists noting:

There are gay North Americans who share our objectives. Our policy is not to exclude them though we require a clear understanding of revolutionary anti-imperialistic priorities and TOTAL [emphasis added] identification with the Political Objectives of the VB (Venceremos Brigade, 1981: 98-100).

These two events, the Cuban Congress and the VB's revised policy statement unleashed a political tempest. The US Gay Revolutionary Party swiftly condemned these policies as reactionary.

\footnotetext{
${ }^{11}$ See Lekus, 2010; Lumsden, 1996.

${ }^{12}$ The VB policy statement generated many political reverberations including a group of gay students at UC-Berkeley who protested a VB meeting on their campus. In 1976, the gay student caucus at the People's College of Law, tried unsuccessfully to prevent the VB from using school facilities until they revised their policy on gays. The Black and La Raza student caucuses both voted in favour of allowing the VB on campus. Also see Ferro, 1975 for a discussion about how the D.C. faggots successfully blocked a VB fundraiser because of its exclusionary politics towards gay liberation.
} 
The fight of the Cuban and other Third World peoples against the imperialism of the US and its lackeys cannot be won by maintaining attitudes of cultural and sexo-economic systems which support and are nurtured by sexism, male individualism, capitalism, and imperialism (...) Gay people are not one more group struggling for liberation. We are, and have always been considered the scum of the earth, but we are you; we are everywhere. The gay revolution is basic because it will destroy the sexual and social roles which are at the bottom of all exploitation, establishing the mutuality of relationship between all people (Jay and Young, 1992: 247).

The Gay Committee of Returned VB Brigadistas likewise released a fiery response to these two events:

We, as gay North Americans who have identified and supported the Cuban revolution through our participation in VB, denounce the anti-homosexual policy formulated at the recent Conference on Education and Culture and endorsed by the Cuban government (...) We have supported the progressive economic policies of the revolution and have been excited and encouraged by indications of a developing cultural revolution towards the liberation of women in all areas of life. Inherent in socialism and socialist practice is the equalization of power among all people... It is each person's revolutionary responsibility to be critical of the racist and sexist institutions that perpetuate divisions among us. There cannot be a revolution, no truly socialist society, until we remove walls of self-hatred that separates us from ourselves and other people. A policy of ruthless and incessant persecution of gay people is contradictory to the needs of all people, and such a policy is reactionary and fascist (Jay and Young, 1992: 249-50).

These gay brigadistas also denounced the VB National Committee for its unwillingness to critique Cuban state sanctioned homophobia as well as its non-recognition of gay liberation politics and homophobia. The gay brigadistas concluded that the VB National Committee functioned as 'agents of a sexist hierarchy. They, in their liberalism, have not engaged in critical relationship with either the Cuban people or with the revolutionaries here' Jay and Young, 1992: 249-50).

At the same time, other gay and feminist brigadistas glossed over Cuban homophobia by excusing Cuba since it was not mandating how US activists should approach gay liberation in the US. Heidi Staffens, for example, noted:

Cuba is not North America. Our revolution will not look like the Cuban revolution. The system we are fighting is the same---its manifestations are vastly different. The Cubans recognise this--they are extremely interested in the Women's Liberation Movement and they have invited Gay liberation people to their country even though feminism has little meaning in Cuba and homosexuals are not part of their revolutionary program (Staffens, 1971).

Indeed, many activists believed that homophobia in the US, not in Cuba, was more important to confront. Additionally, many argued that ending the US embargo would help to eliminate homophobia and sexism in Cuba by alleviating underdevelopment in Cuba.

Not all brigadistas, however, were persuaded by the argument that the revolutionary process would heal homophobia. Gay activist Allen Young, who had participated on the first VB and served on the National Committee, denounced both the US left and Cuba for sidelining the issue of homophobia. Another gay brigadista noted the painful tensions that ensued about the Gay caucus on the $3^{\text {rd }}$ brigade including the suspicions that gay people in general could not relate to Third World struggles. Despite these tensions within the brigades and with Cuba, she felt that there were moments when she felt deep revolutionary unity on the brigades despite:

blacks thinking there might be racism, gay people knowing there was going to be anti-gay sentiment, women knowing that the woman's role in Cuba was pretty bad...yet there were moments when there was a connection, a real live connection (Jay and Young, 1992: 234).

Leslie Cagan, a gay brigadista who had gone on and organised numerous VB trips, was rejected from going on the VB's tenth anniversary brigade which she attributed to her coming out as a lesbian. Despite this exclusion and Cuban homophobia, she remained optimistic about the Cuban revolution.

What is striking about Cuba is the ongoing nature of their revolution. What's working and what isn't, what can be done better, how do you not get caught in patterns that may shut off creativity, how do you keep a revolutionary process alive and dynamic? There is, in Cuba, a deep understanding that the revolution is not static, it does not begin and end on a given date. The sense of long-term struggle is something we in this country would do well to learn from. Go to Cuba and ask the hard questions. Experience a 30-year-old revolution in the process of continual growth and redevelopment. And then come back home and challenge the outdated, reactionary policies of our own country (Cagan, 1989: 32). 


\section{CONCLUSION}

Despite the many complications and barriers that accompanied their transnational travels and political actions, many brigadistas were deeply impacted by their VB experiences and the life-long friendships they made on the brigades. The reverberations of their travels included anti-imperialist activism and political education about Cuba back in the US, repeated travel to Cuba, and ongoing political exchanges with Cuban activists. The intimacy and deep immersion of the brigade experiences brought together an extremely diverse group of US radical activists who engaged in the emotionally intense process of interrogating political divides, geographic and relational borders, and the links between the local and the global while living in an unsettling and highly politicised transnational space.

Some brigadistas continued their solidarity work not only by writing about racism and Third World Women for the VB Educational Commission, but they also published accounts of their experiences in numerous radical publications such as Off Our Backs, Journal of Women's Liberation, Triple Jeopardy, Souls, and the Black Scholars. One of the most direct links between the VB and US women of colour activists was the founding of the West Coast chapter of the Third World Women's Alliance (TWWA) that grew out of political networks and friendships established on the VB. The TWWA raised money for and sponsored the Los Venceremitos, a project that sent US children to an international summer camp in Cuba as guests of a Cuban youth organisation. The TWWA magazine, Triple Jeopardy, regularly published stories supporting the Cuban revolution. For example, it reported on US rightwing violence against Cuban solidarity groups including the bombing of the Center for Cuban Studies, the VB sponsored Cuba Expo: Festival of Revolutionary Change in NYC, and VB recruitment efforts. Activists such as Linda Burnham and Miriam Louie would continue to be key players in multi-ethnic organisations subsequent to TWWA including the Women of Color Resource Center. Significantly, Burnham organised subsequent solidarity delegations of women of colour to UN women's conferences in Nairobi and Beijing as well as the World Conference Against Racism.

Both the successes and political fractures that have accompanied the Venceremos Brigades provide important lessons for contemporary transnational organising. The VB has survived numerous political schisms throughout its long history and has proven to be both a forum and a flashpoint for thousands of US activists to confront questions of cultural imperialism, gender/sexualities, racism, and social change strategies. The VB provided opportunities for a diverse group of US activists to come together to debate strategies and barriers for building transnational affinities, for creating strategic alliances and unities among US social justice movements, for confronting the challenges of working across cultural-political-gender-sexual borders, and for subverting rightwing travel bans and blockades as well as challenging state repression and surveillance.

The VB's reading groups, group activist projects, Third World educational forums, political caucuses, and regional organisations provided numerous opportunities for a wide range of US activists to participate in unique and highly politicised projects of work and political education. The brigades made deep and lasting impacts on many radical activists, including life-long friendships and political connections, the consolidation of commitments to internationalism, anti-imperialism, and the importance of challenging classism, cultural arrogance, and reformism in US social justice movements.

At the same time, however, the VB was plagued by ideological rigidities, exclusionary politics, and the primacy of anti-imperialism over other forms of oppression. Over time brigadistas continued to challenge and defy the exclusions, dismissals, and the VB's destructive politics of assigning primacy to anti-imperialism and defining sexism and homophobia as secondary bourgeois concerns. The National Committee never completely controlled the terms of political and personal engagement. The opposition generated by the National Committee's policies on gender and sexuality raised pertinent questions about oppression, intersectionality, and coalition-building that must still be confronted today.

The resurgence of neoliberal-induced economic precarity, authoritarian politics, surveillance, police violence, incarceration, wars on terror, militarism, travel bans, and promised exclusionary walls loom large in our current moment, yet transnational border encounters from the North to the South are flourishing. Many US neoliberal universities are boasting of internationalising their curriculums while hundreds of organisations across a wide political spectrum claim to be without borders including Clowns Without Borders, Bankers Without Borders, and Entrepreneurs Without Borders. Ever-growing networks of feminist activists are engaging in transnational encounters. Some feminists are engaging in anti-capitalist/neoliberal and anti-imperialist global justice struggles while others have been complicit in neoliberal restructuring efforts and mainstreaming gendered reforms. As a result, an increasing number of individuals across a wide political spectrum are traversing geo-political borders and identifying as allies. Some feminist activists, however, fear that easy proclamations of solidarity, alliance, and allyship constitutes an 'ally industrial complex' a corruption of radical spirit and imagination grounded in romanticised and/or rescue/repair-oriented imperialistic humanitarianism (Indigenous Action Media, 2014). While the VB was far from an ideal prototype for feminist transnationalism and coalition building, many of the tensions 
and lessons learned of these revolutionary left travellers remain timely and essential for building sustainable feminist networks across time and space.

\section{REFERENCES}

Adler, M. (1998). Heretic's Heart: A Journey Through Spirit and Revolution. Boston: Beacon Press, Boston.

Baker, S. and Salzman-Webb, M. (1970). Venceremos Part 1 \&2. Off our backs.

Bengelsdorf, C. (1985). On the Problem of Studying Women in Cuba. Race and Class, 27(2), pp. 35-50. https://doi.org/10.1177/030639688502700203

Bengelsdorf, C. and Hageman, A. (1978). Emerging from Underdevelopment. Race and Class, 19(4), 361-78. https://doi.org/10.1177/030639687801900403

Berman, J. (1970). Women in Cuba. Women: A Journal of Liberation, 1(4), 10-16.

Bethel, P. (1970). How Radical U.S. Youth Were Recruited for Cuba. Human Events, 16 May, 13.

Blackwell, M. (2014). Translenguas/Mapping the Possibilities and Challenges of Transnational Women's Organizations across Geographies of Difference. In S. Alvarez and C. De L. Costa (eds.), Translocalities, Translocalidades: Feminist Politics of Translation in Latin/ A Americas. Durham: Duke University Press, pp. 300-320.

Blackwell, M. (2011). iChicana Power: Histories of Feminism in the Chicano Movement. Austin: University of Texas.

Blasius, M. and Phelan, S. (1971). We Are Everywhere: A Historical Sourcebook of Gay and Lesbian Politics. New York: Routledge.

Bread and Roses Collective. (1970). Weathermen politics and the women's movement. In H. Jacobs (ed.), Weathermen, (pp. 192-97). California: Ramparts Press.

Beal, F. (2005). Voices of Feminism-Oral History Project. Interviewed by Loretta Ross. Sophia Smith Collection, Smith College.

Burnham, L. (2005). Voices of Feminism-Oral History Project. Interviewed by Loretta Ross. Sophia Smith Collection, Smith College.

Cagan, L. (1989). Venceremos. Z Magazine. In L. Cagan Papers, NYU archives, pp. 32-33.

Camarano, C. (1971). On Cuban Women. Science \& Society, 35(1), 48-58.

Carty, L. and Mohanty, C. (2015). Mapping Transnational Engagements: Neoliberalism and the Politics of Solidarity. In R. Baksh and W. Harcourt, eds., Oxford Handbook of Transnational Feminist Movements, Oxford: Oxford University Press.

Chase, M. (2015). Revolution Within Revolution: Women and Gender Politics in Cuba, 1952-1962. Chapel Hill: University of North Carolina Press. https://doi.org/10.5149/northcarolina/9781469625003.001.0001

Lumsden, I. (1996). Machos, Maricones, and Gays: Cuba and Homosexuality. Philadelphia: Temple University Press.

Churchill, L. (2007). Exploring Feminist's Complex Relationship with Political Violence: An Analysis of the Weathermen, Radical Feminism, and the New Left, Lilith: A Feminist History Journal, 16, 26-41.

Committee on Internal Security. (1972). The Theory and Practice of Communism in 1972-Part Two: Venceremos Brigades, U.S. Government Printing Office, Washington, DC, October, 16, 18, and 19.

Desai, M. (2015). Critical cartography, theories, and praxis of transnational feminisms. In R. Baksh and W. Harcourt, eds., Oxford Handbook of Transnational Feminist Movements, Oxford: Oxford University Press.

Evans, S. (1980). Personal Politics: The Roots of Women's Liberation in the Civil Rights Movement and the New Left. New York: Vintage.

Falcon, S. (2012). Transnational Feminism and Contextualized Intersectionality at the 2001 World Conference Against Racism. Journal of Women's History, 24(4), 99-120. https:/ / doi.org/10.1353/jowh.2012.0050

Ferguson, A. (1980). Cuba 1980: A Feminist Perspective. Valley Women's Voice, 2(13), 5.

Ghodsee, K. (2010). Revisiting the United Nations Decade for Women: Brief Reflections on Feminism, Capitalism and Cold War Politics in the Early Years of the International Women's Movement. Women's Studies International Forum, 33, 3-12. https://doi.org/10.1016/j.wsif.2009.11.008

Gitlin T. (1987). The Sixties: Years of Hope Days of Rage. London and New York: Bantam Books.

Goodman, B. (1970). Fantastic Voyage, Great Speckled Bird, November 23, 8.

Gosse, V. (1993). Where the Boys Are: Cuba, Cold War America, and the Making of a New Left. London: Verso.

Gordon, L. (1970). Speculations on Women's Liberation in Cuba. Women: A Journal of Liberation, 1(2), 14-15.

Gronbeck-Tedesco, J. (2015). Cuba, the United States, and Cultures of the Transnational Left, 1930-1975. Cambridge: Cambridge University Press. https://doi.org/10.1017/CBO9781316014837

Guerra, L. (2010). Gender Policing, Homosexuality, and New Patriarchy of the Cuban Revolution. Social History, 35(3), 268-89. https://doi.org/10.1080/03071022.2010.487378

Hobson, E. (2016). Lavender and Red: Liberation and Solidarity in the Gay and Lesbian Left. Berkeley: University of California Press 
Indigenous Action Media. (2014). Accomplices Not Allies: Abolishing the Ally Industrial Complex. Available at: http://www.indigenousaction.org/wp-content/uploads/Accomplices-Not-Allies-print.pdf (Accessed 1 June 2017).

Jacobs, H. (1970). Honky Tonk Women. In H. Jacobs, ed., Weathermen (pp.184-191). California: Ramparts Press.

Jay, K. and Young, A. (1992). Gay Revolutionary Party. In K. Jay, and A.Young, eds., Out of the Closets: Voices of Gay Liberation (pp. 247-251). New York: NYU Press.

Jay, K. and Young, A. (1992). Committee of Gay Returned Brigadistas. In K. Jay, and A.Young, eds., Out of the Closets: Voices of Gay Liberation (pp. 247-251). New York: NYU Press.

Jay, K. and Young, A. (1992). On the VB: A Forum. In K. Jay, and A. Young, eds., Out of the Closets: Voices of Gay Liberation (pp. 228-243). New York: NYU Press.

Johnson-Odim, C. (1991). Common Themes, Different Contexts, Third World Women and Feminism. In C. Mohanty, A. Russo, and L. Torres, eds., Third World Women and the Politics of Feminism. Indiana: Indiana University Press.

Khasnabish, A. (2008). Zapatismo: Beyond Borders: New Imaginations of Political Possibility. Toronto: University of Toronto. https://doi.org/10.3138/9781442689695

Latner, T. (2013). Irresistible Revolution: Cuba and American Radicalism, 1968-1992, Ph.D. dissertation. Irvine: University of California.

Lekus, I. (2010). Queer Harvests: U.S. Homophobia in the U.S. New Left and the Venceremos Brigades to Cuba. Radical History Review (89), 57-91.

Levinson, S. and Brightman, C. (1971). Venceremos Brigade: Young Americans Sharing the Life and Work of Revolutionary Cuba. New York: Simon and Schuster.

Liberation News Service. (1969). Apply for the Venceremos Brigade, Liberation News Service, 25 September.

Louie, M. C. (2008). Triple Jeopardy and the Struggle. Solidarity: A Socialist, Feminist, Anti-Racist Organization. Available at: https://www.solidarity-us.org/node/1486 (Accessed 27 February 2018).

Mohanty, C. T. (2003). Feminism Without Borders: Decolonizing Theory, Practicing Solidarity. Durham: Duke University Press. https://doi.org/10.1215/9780822384649

Martell, E. (1998). In the Belly of the Beast: Beyond Survival. In A. Torres and J. Velazquez (eds.), The Puerto Rican Movement: Voices of the Diaspora. Philadelphia: Temple University Press.

Martinez, E. S. (1969). The Youngest Revolution: A Personal Report on Cuba. New York: Dial Press.

Nelson, M. (1968).Cuban Women, Voice of Women's Liberation Newsletter, June.

Pulido, L. (2006). Black, Brown, Yellow and Left: Radical Activism in Los Angeles. Berkeley: University of California Press.

Rothkrug, B. and Whitehead, S. (undated). Revolution of Cuban Women, Liberation News Service (pp.1-6). Ann Ferguson papers: UMASS-Amherst archives.

Spencer, J. G. (2008). Living for the Revolution: Black. Feminist Organizations, 1968-1980 Durham: Duke University Press.

Serra, A. (2007). The New Man in Cuba: Culture and Identity in the Revolution. Gainesville: University Press of Florida.

Staffens, H. (1971). Revolutions are Never Easy: a hard look out movement, sexuality in Cuba, and what happened on the Venceremos Brigade. Off our backs, 2(2), 37-40.

U.S. Congressional Record. (1970). The Venceremos Brigades-Agrarians or Anarchists? March 16, pp. $7462-67$.

Van Gosse, K. (2005). Rethinking the New Left: An Interpretative History. London: Palgrave. https://doi.org/10.1007/978-1-4039-8014-4

Venceremos Brigades. (1971). Political Objectives of the VB, Turquino, 4-5 September.

Venceremos Brigades Educational Commission. (1974). Four Years of Building Solidarity with Cuba. Cuba Va Series of the Venceremos Brigade, University of Michigan Special Collections.

Venceremos Brigades. (undated). Venceremos in Cuba. Leslie Cagan Collection. Tamiment Library: NYU.

Weber, C. (2006). Visions of Solidarity: U.S. Peace Activists in Nicaragua. London and New York: Lexington Books.

Whitman, K. (1972). Struggling. Women: A Journal of Liberation, 3(1), 69.

Wu, J. T-Z. (2013). Radicals on the Road: Internationalism, Orientalism, and Feminism During the Vietnam Era. New York: Cornell.

Young, C. (2006). Soul Power: Culture, Radicalism, and the Making of the Third World Left. Durham: Duke University Press. https://doi.org/10.1215/9780822388616

Citation: Tice, K. W. (2018). The Politics of US Feminist Internationalism and Cuba: Solidarities and Fractures on the Venceremos Brigades, 1969-89. Feminist Encounters: A Journal of Critical Studies in Culture and Politics, 2(1), 03. https://doi.org/10.20897/femenc.201803

Copyright (C) 2018 by Author/s and Licensed by Lectito BV, Netherlands. This is an open access article distributed under the Creative Commons Attribution License which permits unrestricted use, distribution, and reproduction in any medium, provided the original work is properly cited. 